\title{
Consensus
}

Volume 34

Issue 1 Theology and Context(s)

Article 14

2012

\section{Documents and Images for the Study of Paul}

Oscar Cole-Arnal

Waterloo Lutheran Seminary, ocole@wlu.ca

Follow this and additional works at: http://scholars.wlu.ca/consensus

Part of the History of Christianity Commons

\section{Recommended Citation}

Cole-Arnal, Oscar (2012) "Documents and Images for the Study of Paul," Consensus: Vol. 34 : Iss. 1 , Article 14. Available at: http://scholars.wlu.ca/consensus/vol34/iss1/14

This Book Reviews is brought to you for free and open access by Scholars Commons @ Laurier. It has been accepted for inclusion in Consensus by an authorized editor of Scholars Commons@ Laurier. For more information, please contact scholarscommons@wlu.ca. 


\section{Book Review}

\section{Documents and Images for the Study of Paul}

Elliott, Neil and Mark Reasoner, eds.

Minneapolis: Fortress Press, 2011

Although not a "New Testament" scholar by profession, I have taught courses on Paul occasionally. Should I have the opportunity to do so again, this collection of relevant documents and images would be one of two books I would require for that course. The following description of Documents and Images for the Study of Paul will flesh out why I find this book so very important for Pauline studies:

1. Overall, through the use of translated primary texts and images

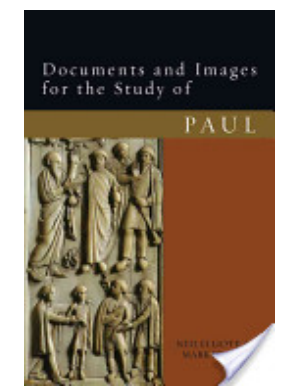
(statues, mosaics, etc.) Neill Elliott and Mark Reasoner provide a setting for Paul and his letters within the milieu of his apostolic living and operating. For too long the "Scriptural" text has stood part from concrete reality as simply divine words from heaven which we Christians must believe and whereby we must live. After all, if we are an "incarnational" people then our Holy Writ must be GROUNDED LITERALLY in the living breathing reality from which it emerged. This book accomplishes that task magnificently.

2. Then, step by step the two editors provide themes whereby Paul is grounded within his world in very specific ways by showing how he is the same as, and different from, the environments that shaped him. Highlighted sections include Paul's selfawareness, Paul as letter-writer, Paul's Gospel, his Jewish heritage, his place within the assemblies of Jesus believers, etc. Just by way of one example, chapter 3, "The Gospel of Augustus," has texts, inscriptions and images of the New Imperial World Order, the "Pax Romana" of Caesar Augustus. After reading this section one is aware of the world Paul confronted with his alternative. Hence we are invited to see Pauline language as not "other-worldly" but as counter to and offering an alternative to imperial power and prestige.

3. The very structure of each chapter itself enhances the above positive qualities. First we are provided with a general introduction, followed by brief descriptions of the chosen primary source used. Then comes the quoted source and/or image itself--the heart of each mini-section. Finally, at the close of each chapter are two parts: 1). "Questions for Reflection" (to guide discussion) and 2). "For Further Reading" (providing a solid bibliography for those who desire to study and deepen that chapter's particular theme).

In conclusion, I have a particular passion for this collection. The scholars who edit the book, especially Neill Elliott, represent those academics who see the Gospel embodied by Jesus as the very antithesis of imperialism--- its power, its arrogance, its super-wealth, 
its elitism, its militarism, etc. In this book the editors give us hard data to help us recover a vulnerable faith community in order to confront such seemingly unassailable power in the name of a Lord and Savior who lives and dies in solidarity with all those marginalized and shoved aside.

Oscar Cole-Arnal

Waterloo Lutheran Seminary

Waterloo, Ontario 